\title{
In vitro embryo production in Nelore cows supplemented with calcium salts of long-chain fatty acids
}

\section{Produção de embriões in vitro em vacas Nelore suplementadas com sais de cálcio e ácidos graxos de cadeia longa}

\author{
Moacir Rogério de Souza ${ }^{1}$; Luciano Soares de Lima ${ }^{2}$; Fabio Luiz Bim Cavalieri³; \\ Luiz Paulo Rigolon ${ }^{4}$; Wallacy Barbacena Rosa dos Santos ${ }^{1}$; Josmar Mazucheli ${ }^{5}$; \\ Alexandre Leseur dos Santos ${ }^{6}$; Geraldo Tadeu dos Santos ${ }^{4 *}$
}

\section{Highlights:}

Dietary protected Ca-LCFA did not alter the pregnancy rate of Nelore cows.

Dietary protected Ca-LCFA did not affect in vitro embryo production in Nelore cows.

Oocyte cleavage was not altered by dietary Ca-LCFA in Nelore cows.

\begin{abstract}
This study was performed to evaluate the effects of supplementation of lactating Nelore cows with calcium salts of long-chain fatty acids (Ca-LCFA) of soybean oil on in vitro oocytes competency, cleavage rate, embryo production rate, pregnancy rate, and sex ratio of transferred embryos. Fifteen multiparous Nelore cows grazed on a Tifton 85 pasture were allotted to two treatments: (1) supplement without fat inclusion (CONT, $\mathrm{n}=6$ ) and (2) supplement containing $47.2 \mathrm{~g} \mathrm{Ca}-\mathrm{LCFA} / \mathrm{kg}$ (to provide an intake of $0.2 \mathrm{~kg}$ Ca-LCFA/day) based on dry matter $(\mathrm{n}=9)$. Animals were subjected to $2.53 \pm 1.35$ rounds of consecutive ovum pick up at intervals of $27.65 \pm 21.72$ days. Oocytes were morphologically evaluated, selected, maturated, fertilized, and cultivated for embryo production in vitro and then transferred into recipients who had previously undergone an embryo transfer protocol at a fixed time. The number of aspirated oocytes, the proportion of viable oocytes, cleavage rate, embryo percentage, pregnancy rate, and sex ratio were not affected when Nelore cows were supplemented with Ca-LCFA of soybean oil compared with non-supplemented Nelore cows. In conclusion, our results suggest that feeding a supplement containing $47.2 \mathrm{~g}$ Ca-LCFA $/ \mathrm{kg}$ (to provide an intake of $0.2 \mathrm{~kg} \mathrm{Ca-LCFA} /$ day) to Nelore cows does not affect in vitro embryo production in lactating Nelore cows. However, further studies using higher dietary doses of fat could be useful to determine the potential of fat supplementation to improve in vitro embryo production.
\end{abstract}

Key words: Beef cattle. Bos indicus. Fatty acids. Oocytes. Ovum pick up. Pregnancy.

\footnotetext{
1 Discentes do Curso de Doutorado do Programa de Pós-Graduação em Zootecnia, Universidade Estadual de Maringá, UEM, Maringá, PR, Brasil. E-mail: moacir_vet@hotmail.com; wallacyzoot@hotmail.com

2 Prof. Dr., Departamento de Zootecnia, Universidade Federal de Minas Gerais, UFMG, Belo Horizonte, MG, Brasil. E-mail: lucianodelima@ufmg.br

3 Prof. Dr., UniCesumar, Centro de Biotecnologia e ICETI-Instituto Cesumar de Tecnologia e Informação, Maringá, PR, Brasil. E-mail: fbim52@hotmail.com

4 Profs. Drs., Departamento de Zootecnia, Universidade Estadual de Maringá, UEM, Maringá, PR, Brasil. E-mail: rigolon@wnet. com.br; gtsantos50@gmail.com

5 Prof. Dr., Departamento de Estatística, UEM, Maringá, PR, Brasil. E-mail: jmazucheli@uem.br

6 Prof. Dr., Departamento de Agronomia, Universidade Federal do Paraná, UFPR, Palotina, PR, Brasil. E-mail: aleseur@gmail. com
}

* Author for correspondence 


\section{Resumo}

Este estudo foi realizado para avaliar os efeitos da suplementação de vacas Nelores em lactação com sais de cálcio de ácidos graxos de cadeia longa (Ca-SCACL) feitos com óleo de soja sobre a competência in vitro de oócitos, taxa de clivagem, taxa de produção de embriões, taxa de prenhez e proporção de sexo de embriões transferidos. Foram utilizadas 15 vacas Nelore (lactantes, multíparas e mantidas em pastagem de Tifton 85) distribuídas em dois tratamentos: (1) suplemento sem inclusão de lipídios (CONT, n=6) e (2) suplemento contendo 47,2 g Ca-SCACL/kg (para proporcionar uma ingestão de 0,2 kg Ca-SCACL/ dia) com base na matéria seca $(\mathrm{n}=9)$. Os animais foram submetidos a 2,53 $\pm 1,35$ rodadas consecutivas de aspiração folicular a intervalos de 27,65 $\pm 21,72$ dias. Os oócitos foram avaliados morfologicamente, selecionados, maturados, fertilizados e cultivados para produção de embriões in vitro. Em seguida, os embriões foram transferidos para receptoras previamente submetidas a um protocolo de transferência de embriões em tempo fixo. O número de oócitos aspirados, a proporção de oócitos viáveis, a taxa de clivagem, a porcentagem de embriões, a taxa de prenhez e a proporção de sexo de embriões não foram afetados quando as vacas Nelore foram suplementadas com Ca-SCACL de óleo de soja em comparação com as vacas Nelore não suplementadas. Em conclusão, nossos resultados sugerem que suplemento contendo 47,2 g de Ca-SCACL/ $/ \mathrm{kg}$ (para fornecer uma ingestão de $0,2 \mathrm{~kg}$ de Ca-SCACL) não afeta a produção in vitro de embriões de vacas Nelore em lactação. No entanto, novos estudos utilizando doses mais altas de gordura na dieta poderiam ser úteis para determinar o seu potencial sobre produção embrionária in vitro.

Palavras-chave: Ácidos graxos. Bos indicus. Fertilização in vitro. Gado de corte. Gestação. Oócitos.

\section{Introduction}

Recent decades have been marked by constant searching for animals with high genetics. Consequently, new biotechnologies have been developed to meet the needs of breeders. In this context, we highlight the biotechnology involved in assisted reproduction. Typically, assisted reproductive biotechnologies are those related to manipulation of gametes and embryos, such as artificial insemination (AI), timed artificial insemination (TAI), multiple ovulation and embryo transfer, and follicular aspiration coupled with in vitro embryo production (OPU-IVEP) (Bó, Cedeño, \& Mapletoft, 2019; Pontes et al., 2009).

OPU-IVEP has become a very important tool for genetic improvement and may help to increase the number of descendants when compared with other biotechnologies. Despite major recent advances in OPU-IVEP, results have suggested low efficiency. Indeed, studies have reported blastocyst production ranging from $10 \%$ to $40 \%$ (Lonergan \& Fair, 2008; Rizos et al., 2008) and pregnancy rates ranging from $30 \%$ to $40 \%$ (Peterson \& Lee, 2003; Pontes et al., 2009; Siqueira et al., 2009). These low results are partially related to conditions of maturation, fertilization, and culture in vitro. However, the efficiency of this biotechnology is associated with the capacity of oocytes to develop in vitro (Rizos, Ward, Duffy, Boland, \& Lonergan, 2002). Thus, studying potential factors influencing oocyte in vitro development could provide insight into practices that may improve the efficiency of OPU-IVEP.

It is well established that nutrition impacts bovine female fertility (Swecker, 2014) and that lipids, especially polyunsaturated fatty acids (PUFA), have a major role in ruminant fertility (Hiller, 2014). Potential mechanisms may include improved dietary energy density (Ferguson, Sklan, Chalupa, \& Kronfeld, 1990), altered follicle development, increased concentrations of progesterone (Lopes, Scarpa, Cappellozza, Cooke, \& Vasconcelos, 2009), suppressed luteolytic signals around maternal recognition of pregnancy (Mattos, Staples, \& Thatcher, 2000), and improved embryo quality (Cerri et al., 2009). Lipids are integral components of membranes and they are stored in droplets that supply energy and lipids for membrane syntheses during embryonic development (Hiller, 
2014). Aardema et al. (2011) reported that highquality oocytes contained more oleic and linoleic acids in cellular lipid droplets than low-quality oocytes. Usually, beef cattle diets contain low (2\%) concentrations of long-chain fatty acids (LCFA) that are predominantly PUFA (Santos, Bilby, Thatcher, Staples, \& Silvestre, 2008). Thus, supplementation with rumen-protected PUFA, such as calcium salts of LCFA (Ca-LCFA), has become an important practice in livestock production. Indeed, Ca-LCFA supplementation coupled with TAI was reported to improve pregnancy rate in Bos indicus beef cows (Lopes et al., 2009; Lopes, Cooke, Reis, Peres, \& Vasconcelos, 2011). A recent study (Cooke, 2019) reported that post-artificial insemination Ca-LCFA supplementation favors incorporation of omega-6 fatty acid into maternal and embryonic tissues, which enhances interferon-tau synthesis by the conceptus and increases pregnancy rates to fixed-time $\mathrm{AI}$ in $B$. indicus and B. taurus beef cows. However, fat supplementation coupled with OPU-IVEP has shown inconsistent results. For dairy cows, few studies (Bilby et al., 2006; Fouladi-Nashta et al., 2009; Ponter, Guyader-Joly, Nuttinck, Grimard, \& Humblot, 2012) have shown any effects of different dietary fat sources on the ability of oocytes to develop to the blastocyst stage while other studies showed positive (Fouladi-Nashta, Gutierrez, Gong, Garnsworthy, \& Webb, 2007) or negative (Adamiak, Powell, Rooke, Webb, \& Sinclair, 2006) effects. However, these results, observed in high producing cows, may not necessarily be similar to those in grazing beef cows given differences in seasonal feed availability, dry matter intake, passage rate, and milk production that affect nutrient metabolism and also reproductive concentrations. Meikle et al. (2018) reported, among other metabolic differences, a lower steroid plasmatic concentration in dairy cows compared with beef cows. These authors attributed such phenomena to a high hepatic flux (intakelactation) that affects the clearance of E2 and P4 in dairy cows. A recent study (Souza et al., 2016) was performed with Nelore cows supplemented with rich omega-6 Ca-LCFA to evaluate the effects on the production and quality of aspirated cumulusoocyte complexes (COC) of lactating Nelore cows. The authors reported no advantages of Ca-LCFA supplementation on COC production and quality. However, Souza et al. (2016) did not evaluate the effects of Ca-LCFA on in vitro embryo production.

Thus, the present study was performed to evaluate the effects of supplementing Nelore cows with Ca-LCFA made from soybean oil (rich in omega-6) on embryo production. The competence of aspirated oocytes, cleavage rate, embryo production rate, pregnancy rate, and the proportion of males to females were evaluated.

\section{Material and Methods}

\section{Experimental treatments and design}

All animals were cared for following the Nacional Council for Control of Animal Experimentation. This study was performed at three different locations: (1) Rancho da Matinha, Uberaba, MG, Brazil where follicular aspirations in donors were performed; (2) Vitrogen ${ }^{\circledR}$ in vitro fertilization lab, Uberaba, MG, Brazil; and (3) Fazenda Santo Antônio, Cumaru do Norte, PA, Brazil where embryos were transferred to recipients.

Fifteen Nelore (Bos taurus indicus) cows were used as donors. At the beginning of the experiment, cows averaged $66.1 \pm 20.8$ months of age, 3.9 \pm 1.8 parturitions, $32.3 \pm 14.7$ days postpartum, $597.2 \pm 67.3 \mathrm{~kg}$ body weight, and BCS $=6 \pm 0.1$ on a nine-point scale (Richards, Spitzer, \& Warner, 1986). Before starting the experiment, reproductive evaluations were performed using an ultrasound device (Aloka SSD-500, Tokyo, Japan) fitted with a $5 \mathrm{MHz}$ linear rectal probe (Aloka UST5820-5, Tokyo, Japan) to identify possible abnormalities or reproductive pathologies. Lactating Nelore cows (60-120 days postpartum and $\mathrm{BCS}=4)$ were used as embryo recipients. All cows were free from infectious and reproductive diseases. 
Donors were randomly assigned to one of two dietary treatments: 1$)$ supplement $(n=6)$ without fat inclusion (CONT), and 2) supplement $(\mathrm{n}=9)$ containing $47.2 \mathrm{~g} / \mathrm{kg}$ calcium soap of long-chain fatty acid (Ca-LCFA; Lacto Plus ${ }^{\circledR}$, Itajaí, SC, Brazil) in the dry matter (DM). The Ca-LCFA contained, on a total fatty acid basis, $0.71 \%$ of $\mathrm{C} 12: 0,0.30 \%$ of $\mathrm{C} 14: 0,13.79 \%$ of $\mathrm{C} 16: 0,0.10 \%$ of $\mathrm{C} 16: 1 \mathrm{cis}-7$, $0.10 \%$ of $\mathrm{C} 17: 0,5.27 \%$ of $\mathrm{C} 18: 0,5.68 \%$ of C18:1trans $-9,26.17 \%$ of C18:1cis $-9,42.19 \%$ of C18:2cis-6, $3.35 \%$ of C18:3cis-9,cis-12,cis- 15 ,
$0.41 \%$ of $\mathrm{C} 20: 0,0.30 \%$ of $\mathrm{C} 20: 1,0.91 \%$ of $\mathrm{C} 21: 0$, and $0.71 \%$ of $\mathrm{C} 22: 0$. The experimental dose of $\mathrm{Ca}-$ LCFA was chosen based on a previous study (Souza et al., 2016) where this ingredient was used to evaluate the effects on oocyte production in Nellore cows. Supplements (Table 1) were formulated to meet requirements for beef cows according to the National Research Council [NRC] (1996) and were offered once a day $(8: 00 \mathrm{~h})$ over 100 days. The supplement containing Ca-LCFA was offered to provide an intake of $0.2 \mathrm{~kg} \mathrm{Ca-LCFA} / \mathrm{cow} /$ day.

Table 1

Ingredients and chemical composition of experimental supplements

\begin{tabular}{|c|c|c|}
\hline \multirow[t]{2}{*}{ Items } & \multicolumn{2}{|c|}{ Treatments } \\
\hline & CONT & LCFAS \\
\hline \multicolumn{3}{|l|}{ Ingredients (g/kg DM) } \\
\hline Corn silage & 501.2 & 528.4 \\
\hline Ground corn & 319.3 & 216.9 \\
\hline Soybean meal & 128.7 & 165.1 \\
\hline Molasses & 12.5 & 11.8 \\
\hline Limestone & 10.0 & 0.0 \\
\hline Urea & 7.0 & 7.1 \\
\hline Dicalcium phosphate & 3.0 & 4.2 \\
\hline Antioxidant(BHT) & 0.5 & 0.5 \\
\hline Mineral mixture $^{1}$ & 18.0 & 18.9 \\
\hline Lacto Plus $^{\circledR}$ & - & 47.2 \\
\hline \multicolumn{3}{|l|}{ Nutrient composition } \\
\hline Dry matter (g/kg) & 417.2 & 405.4 \\
\hline Organic matter $(\mathrm{g} / \mathrm{kg} \mathrm{DM})$ & 949.5 & 944.5 \\
\hline Crude protein (g/kg DM) & 149.5 & 155.9 \\
\hline Ether extract (g/kg DM) & 25.2 & 35.4 \\
\hline Neutral detergent fiber (g/kg DM) & 271.6 & 279.4 \\
\hline Acid detergent fiber (g/kg DM) & 192.4 & 198.6 \\
\hline
\end{tabular}

Abbreviations: CONT, supplement without fat inclusion. LCFAS, long-chain fatty acid soaps. BHT, butylated hydroxytoluene. DM, dry matter.

${ }^{1}$ Contained (per kg as is basis): Ca 123.0 g; P 90.0 g; S 18.0 g; Na 141.0 g; Co 60.0 mg; Cu 1,500 mg; Cr 20.0 mg; Fe 1,800 mg; I $75.0 \mathrm{mg}$; Mn 1,800 mg; Se $17.0 \mathrm{mg}$; Zn 4,500 mg; and F $900.0 \mathrm{mg}$.

Donors were grazed on a Tifton 85 (Cynodon spp) pasture throughout the experiment. The pasture was divided into eight 0.55 ha paddocks, which were grazed rotationally by groups. Each group of cows was moved to a new paddock every 7-8 days, allowing for 25 days of rest. Pasture samples were plucked by hand from each paddock on the first and last days of grazing to evaluate the composition. 
Tifton 85 contained, on a DM basis, $185.7 \mathrm{~g} / \mathrm{kg}$ of crude protein, $741.1 \mathrm{~g} / \mathrm{kg}$ of neutral detergent fiber, $344.8 \mathrm{~g} / \mathrm{kg}$ of acid detergent fiber, and $19.7 \mathrm{~g} /$ $\mathrm{kg}$ of ether extract. Embryo recipients were grazed on a Tanzania grass (Panicum maximum). Mineral supplement and water were always available to donors and recipients.

DM was evaluated according to method no. 934.01 of the Association of Official Analytical Chemists [AOAC] (1998). Total $\mathrm{N}$ was determined with a Tecnal TE-036/1 (Tecnal, Piracicaba, SP, Brazil) following method no. 988.05 of the AOAC (1998). Ether extraction from diets was conducted with Tecnal TE-044/1 according to procedure no. 920.39 of the AOAC (1998). The concentration of neutral detergent fiber (aNDF), including residual ash, was evaluated as described by Mertens (2002) by using heat-stable $\alpha$-amylase and sodium sulfite. The ADF content was determined according to method 973.18 of the AOAC (1998). The aNDF procedure was adapted to accommodate the use of the Ankom ${ }^{200}$ Fiber Analyzer (Ankom Technology Corp., Fairport, NY, USA).

\section{Follicular aspiration in donors}

After 14 days of adaptation to the experimental treatments, all donors were subjected to $2.53 \pm$ 1.35 rounds of follicular aspiration consecutive ovum pick up (OPU), at intervals of $27.65 \pm$ 21.72 days. OPU was performed using ultrasound (Aloka SSD-500, Tokyo, Japan) fitted with a transvaginal guide (WTA, Cravinhos, SP, Brazil) for follicular puncture, with a convex transducer of $5 \mathrm{MHz}$ (Aloka UST994T-5, Tokyo, Japan). These devices were attached to an $18 \mathrm{G}$ short disposable needle system (BD Precision Guide, São Paulo, SP, Brazil). Before OPU procedures, the rectum was emptied, and the perineum and vulva were washed with running water before being wiped with a paper towel. Cows were given a local anesthetic agent of 3-5 $\mathrm{mL}$ of $2 \%$ lidocaine without vasoconstrictors (Lidovet, Bravet, Engenho Novo, RJ, Brazil), which was injected epidurally between the last sacral and first caudal vertebrae.

Ovaries of donors were viewed via ultrasonography, and follicular fluid was aspirated from follicles that were $\geq 3 \mathrm{~mm}$. The aspiration was performed via continuous negative pressure ( $80 \mathrm{mmHg}$, low rate equivalent of $13 \mathrm{~mL} / \mathrm{min}$ ) by using a vacuum pump (WTA, Cravinhos, SP, Brazil). Follicles were aspirated by using a needle connected to a puncture system (WTA, Cravinhos, $\mathrm{SP}$, Brazil) with a $50-\mathrm{mL}$ polypropylene tube (TPP, Trasadingen, Schaffhausen, Switzerland). The needle system was rinsed before and after each aspiration with a sterile saline solution (phosphate-buffered saline $(\mathrm{pH} 7.4)+1 \%$ of fetal bovine serum $+5 \mathrm{UI} / \mathrm{mL}$ of sodium heparin). Aspirated follicular fluid from each cow was rinsed with a saline solution (phosphate-buffered saline, $\mathrm{pH}$ 7.4), and then filtered using 75- $\mu \mathrm{m}$ embryo filters (WTA, Cravinhos, São Paulo, Brazil). The retained content was transferred to a Petri dish retentate, after which the oocytes were counted and evaluated using a stereomicroscope (SMZ-645, Nikon, Tokyo, Japan).

Oocytes were classified as either viable or non-viable according to the number of layers of cumulus cells surrounding the oocytes and based on their cytoplasmic consistency (Lonergan \& Fair, 2008). Oocytes that were found without layers of cumulus cells, with expanded cumulus cells, with cumulus cells in regression, and degenerated oocytes were considered as non-viable. After classification, oocytes were washed in a holding medium (tissue culture medium-199 (Gibco, USA)) supplemented with $10 \% \mathrm{vol} / \mathrm{vol}$ fetal bovine serum, antibiotic, and pyruvate. Oocytes were loaded into cryotubes which were placed into a portable incubator (WTA, Cravinhos, SP, Brazil) set at 37 ${ }^{\circ} \mathrm{C}$ and transported to the lab. The average transport time was $5 \mathrm{~h}$. 


\section{In vitro embryo production}

Harvested COC from grade I, II, and III were matured in $70-\mu \mathrm{L}$ microdrops of TC-199 with salts of Earle (Invitrogen, Carlsbad, CA) supplemented with $10 \%$ (vol/vol) bovine fetal serum, $22 \mu \mathrm{g}$ of pyruvate $/ \mathrm{mL}, 50 \mu \mathrm{g}$ of gentamicin $/ \mathrm{mL}, 0.5 \mu \mathrm{g}$ of $\mathrm{FSH} / \mathrm{mL}, 50 \mu \mathrm{g}$ of $\mathrm{LH} / \mathrm{mL}$, and $1 \mu \mathrm{g}$ of estradiol/ $\mathrm{mL}$. Maturation drops were overlaid with mineral oil and placed in a humidified atmosphere of 5\% (vol/vol) $\mathrm{CO}_{2}$ in air for 22 to $24 \mathrm{~h}$ at $38.5{ }^{\circ} \mathrm{C}$. Following maturation, $\mathrm{COC}$ were coincubated with sperm $\left(2 \times 10^{6}\right.$ spermatozoa $\left./ \mathrm{mL}\right)$ in $70-\mu \mathrm{L}$ microdrops (20 COC/microdrop) of fertilization medium (Parrish et al., 1986) supplemented with 10 $\mu \mathrm{g}$ of heparin $/ \mathrm{mL}, 22 \mu \mathrm{g}$ of pyruvate $/ \mathrm{mL}, 50 \mu \mathrm{g}$ of gentamicin $/ \mathrm{mL}, 6 \mathrm{mg}$ of bovine serum albumin free of fatty acids, and PHE solution $(2 \mu \mathrm{M}$ of penicillin, $1 \mu \mathrm{M}$ of hypotaurine, and $0.25 \mu \mathrm{M}$ of epinephrine). Sperm from one Nelore bull previously tested for in vitro fertilization was used. For sperm preparation, semen was thawed in bath water at $35{ }^{\circ} \mathrm{C}$ for 30 seconds and then layered on top of a mini-Percoll gradient $(300 \mu \mathrm{L}$ of $45 \%$ Percoll over $300 \mu \mathrm{L}$ of $90 \%$ Percoll) and then centrifuged at $300 \times \mathrm{g}$ for 20 min. Spermatozoa and COC were coincubated from 15 to $18 \mathrm{~h}$ at $38.5^{\circ} \mathrm{C}$ in a humidified atmosphere of $5 \%(\mathrm{vol} / \mathrm{vol}) \mathrm{CO}_{2}$ in the air.

The day of fertilization was considered as day zero. Following fertilization, presumptive zygotes were cultured in $70-\mu \mathrm{L}$ microdrops of $\mathrm{CR}_{2}$ medium supplemented with $10 \%$ ( $\mathrm{vol} / \mathrm{vol})$ bovine fetal serum, $30 \mathrm{mg} \mathrm{BSA} / \mathrm{mL}$. Zygotes were cultured at $38.5{ }^{\circ} \mathrm{C}$ in a humidified atmosphere of $5 \%$ (vol/ vol) $\mathrm{CO}_{2}$ in the air for seven days. The proportion of oocytes that cleaved was recorded $48 \mathrm{~h}$ after insemination. On day 7 after fertilization, the embryos were morphologically evaluated and classified according to the International Embryo Transfer Society (Robertson \& Nelson, 1998). Then, each embryo was loaded into a $25-\mathrm{mL}$ straw (IMV, Orne, France), placed into a portable incubator (WTA, Cravinhos, SP, Brazil) set at $37^{\circ} \mathrm{C}$, and transported to the farm for transfer to recipients. The average transport time was $8 \mathrm{~h}$.

\section{Embryo transfer into recipients}

To perform embryo transfers, recipients were subjected to TAI. Briefly, cows received an intravaginal P4-releasing (1.9 g) insert (CIDR, Pfizer, São Paulo, Brazil) for eight days coupled with $2 \mathrm{mg}$ of estradiol benzoate (Farmavet, São José do Rio Preto, São Paulo, Brazil) injected intramuscularly (i.m.). On day 5 after insert, 400 UI of equine chorionic gonadotropin (eCG) (Intervet Schering-Plough, São Paulo, Brazil) were injected i.m. After insert removal, cows received $1 \mathrm{mg}$ of estradiol cypionate (ECP, Pfizer, Brasil) and 150 $\mu \mathrm{g}$ of cloprostenol i.m. (Veteglan, Hertape Calier, Brasil). On day 17 after insert, the presence or absence of a corpus luteum (CL) was diagnosed for all cows enrolled in the experiment with an Aloka 500 ultrasound scanner equipped with a linear-array transducer (Aloka, Tokyo, Japan). All cows that were diagnosed as having a CL $(\geq$ $10 \mathrm{~mm}$ ) received a single embryo transfer to the uterine horn ipsilateral to the ovary with the CL via the transcervical method. All procedures were performed by the same person to avoid personal variations. A total of 552 embryos, 153 from the CONT treatment, and 399 from the Ca-LCFA treatment were transferred.

Pregnancy and fetal sex were diagnosed on day 53 after embryo transfer, using an Aloka 500 ultrasound scanner equipped with a linear-array transducer (Aloka, Tokyo, Japan). The fetal sex was determined according to the relative location of the genital tubercle as previously reported (Curran, Kastelic, \& Ginther, 1989).

\section{Statistical analysis}

Data were analyzed using the GLM procedure in SAS (SAS Institute, Cary, NC). Data on aspirated 
oocytes were log-transformed because of the overdispersion presence and assessed by fitting a Poisson regression model and the treatment received by the donor was used as the covariate term according to the following model:

$$
\begin{gathered}
\log \left(\mu_{i}\right)=\log (\text { numbers of aspirations) } \\
+\beta_{0}+\beta_{1} x_{1}+a_{i,}
\end{gathered}
$$

where: $\exp \left(\beta_{0}\right)$ is the mean of oocytes from donors when $\mathrm{x}=0(\mathrm{CONT}), \exp \left(\beta_{1}\right)$ the treatment effect, and $a_{i} N(0$, sigma $)$ is the random effect of donor.

For variables of proportion (viable oocytes, cleavage rate, embryo production rate, pregnancy rate, and sex ratio) binomial distribution was used according to the following model:

$$
\operatorname{Logit}\left(p_{i}\right)=\alpha_{0}+\alpha_{1} x_{1}+a_{i}
$$

where: $\alpha_{0}$ is the chance of "success" for $\mathrm{x}=0$ (T1), $\alpha_{1}$ the effect of treatment, and $a_{t} N(0$,sigma $)$ is the random effect of the donor.

The treatment effect was assessed by the confidence interval inspection (percentiles $\mathrm{P}_{2.5 \%}$ - $\mathrm{P}_{975 \%}$ ) with a $95 \%$ confidence coefficient. As the treatment effect is measured by the ratio between the two estimates, there is no treatment effect at a $5 \%$ level of significance when the intervals $\left[\mathrm{P}_{2,5 \%}\right.$; $\mathrm{P}_{97,5 \%}$ ] showed in the tables have the number 1 (statistical equality among treatment means).

\section{Results and Discussion}

The number of aspirated oocytes, the proportion of viable oocytes, cleavage rate, embryo percentage, pregnancy rate, and sex ratio were not affected
$(\mathrm{P}>0.05)$ when Nelore cows were supplemented with Ca-LCFA of soybean oil compared with nonsupplemented Nelore cows (Table 2). This lack of effect was unexpected, as lipids, especially PUFA, are known to affect bovine reproduction (Hiller, 2014; Swecker, 2014). However, our results on oocyte production are corroborated by those documented previously by Souza et al. (2016) who reported that no differences in aspirated and viable oocytes were observed in Nelore cows supplemented with the same Ca-LCFA daily amount (47.2 g Ca-LCFA/ $\mathrm{kg}$ supplement) as the present study. Similarly, Adamiak et al. (2006) studied supplementation of beef $\times$ dairy heifers with $60 \mathrm{~g} \mathrm{Ca-LCFA} \mathrm{(palm} \mathrm{oil)/}$ $\mathrm{kg}$ DM and reported no effect of treatments on the number of follicles aspirated. It is possible that the experimental dose (47.2 g Ca-LCFA/kg supplement to provide an intake of $0.2 \mathrm{~kg} \mathrm{Ca-LCFA/day)} \mathrm{of} \mathrm{the}$ present study was not high enough to affect oocyte production. However, no difference was observed for the number of aspirated oocytes when dairy cows were supplemented with $0.8 \mathrm{~kg}$ Ca-LCFA/ day versus $0.2 \mathrm{~kg} \mathrm{Ca-LCFA/day} \mathrm{(Fouladi-Nashta}$ et al., 2007), suggesting that a higher dose may also not affect the number of aspirated oocytes in Nelore cows. On the other hand, in the same study, Fouladi-Nashta et al. (2007) reported a tendency (P $=0.076)$ to improved cleavage rate, $72.0 \%$ versus $66.6 \%$, when dairy cows were supplemented with $0.8 \mathrm{~kg} \mathrm{Ca}-\mathrm{LCFA} /$ day and $0.2 \mathrm{~kg} \mathrm{Ca}-\mathrm{LCFA} /$ day, respectively. These authors concluded that there are beneficial effects of an increased level of dietary fat on the developmental potential of oocytes in the high-yielding dairy cow. 


\section{Table 2}

Estimated in vitro embryo production characteristics by follicular aspiration round in Nelore cows supplemented with $0.2 \mathrm{~kg} / \mathrm{d}$ long-chain fatty acids soap (LCFAS)

(Adjusted mean values and 95\% confidence intervals)

\begin{tabular}{lccc}
\hline Item & Control & LCFAS & Treatment Effect $^{1}$ \\
\hline Aspirated oocytes/ovum pick up & & & \\
Mean & 20.9 & 25.4 & 1.31 \\
95\% CI & $11.3-30.6$ & $15.9-34.9$ & 1.67 \\
Viable oocyte percentage & & & \\
Mean & 89.3 & 88.1 & 1.32 \\
95\% CI & $85.4-93.2$ & $85.3-90.9$ & \\
Cleavage rate & & & \\
Mean & 70.7 & 76.1 & 1.60 \\
$95 \%$ CI & $58.8-82.7$ & $67.8-84.4$ & \\
Odds ratio & 2.41 & 3.19 & \\
Embryo percentage & & & \\
Mean & 51.7 & 52.4 & 1.53 \\
95\% CI & $40.5-43.9$ & $62.9-60.8$ & \\
Odds ratio & 1.07 & 1.10 & \\
Pregnancy rate & & & \\
Mean & 38.4 & 39.1 & \\
95\% CI & $29.5-47.3$ & $32.9-45.3$ & \\
Odds ratio & 0.62 & 0.64 & \\
Sex ratio (\% male) & & 53.1 & \\
Mean & 52.7 & $41.6-64.6$ & 1.13 \\
95\% CI & $46.1-59.3$ & & \\
Odds ratio & 1.11 & & \\
\hline
\end{tabular}

${ }^{1}$ Ratio between treatment means.

Similarly, previous studies have also reported other positive effects of increasing dietary fat in cows. For example, Bilby et al. (2006), FouladiNashta et al. (2007, 2009), and Thangavelu et al. (2007) reported higher blastomere numbers in cows fed dietary fat. Although they suggest better embryo quality and pregnancy rate, studies usually do not evaluate the embryo transfer, and then it is difficult to determine the development of embryos in the recipients uterus. The information available on pregnancy rates of Nelore cows fed dietary fats refer to TAI (Lopes et al., 2011, 2009). In these studies, animals were supplemented with fat during different periods $(21,22$, or 28 days) and had a greater $(\mathrm{P}<0.05)$ conception rate than the control group (with no dietary fat). In our study, although the Ca-LCFA supplementation period of the donor was 100 days, the pregnancy rate of the in vitro produced embryos showed no improvement. This suggests that supplementation of $0.2 \mathrm{~kg} \mathrm{Ca-LCFA}$ from soybean oil/day over a $100 \mathrm{~d}$-period does not affect the development and pregnancy of in vitro produced embryos.

Few studies (Gutiérrez-Adán, Behboodi, Andersen, Medrano, \& Murray, 1996; Gutiérrez et al., 2001; Van Wagtendonk-de Leeuw et al., 2000) have shown a slight deviation in the male to female ratio of in vitro produced embryos. In 
these studies, the male embryo percentage has been reported to be higher than $50 \%$ as usually expected. Some researchers have explained this based on the direct effects of PUFA on the sex ratio (Green et al., 2008). Indeed, increased PUFA proportion, especially linoleic acid (C18:2) has been reported to cause changes in follicle growth, ovulation rate, oocyte quality, progesterone synthesis, as well as prostaglandin synthesis and metabolism (Adamiak et al., 2006; Mattos et al., 2000). Additionally, C18:2 has been reported to cause changes in the physical properties and signaling ability of the oocyte (Adamiak et al., 2006; Zeron, Sklan, \& Arav, 2002). All these effects together could render oocytes more prone to fertilization by $\mathrm{Y}$ sperm (Green et al., 2008).

Taking all this together, our results suggest that despite the supplemental fat, reproductive systems of cows from both CONT and Ca-LCFA treatments were provided with a similar nutrient supply which likely accounted for the lack of effect of dietary CaLCFA. Funston (2004) has previously reported that feeding fat to cows or heifers with an adequate body condition score and grazed on good quality pastures may not provide a beneficial effect on reproduction. Indeed, in the present experiment, the animals from both treatments showed ECC $\geq 6$ and were grazed on good quality pasture throughout the experiment.

In conclusion, our results suggest that feeding a supplement containing $47.2 \mathrm{~g} \mathrm{Ca}-\mathrm{LCFA} / \mathrm{kg}$ (to provide an intake of $0.2 \mathrm{~kg} \mathrm{Ca-LCFA/day)} \mathrm{to} \mathrm{Nelore}$ cows does not affect in vitro embryo production in lactating Nelore cows. However, further studies using higher dietary doses of fat could be useful to determine the potential of fat supplementation to improve in vitro embryo production.

\section{Acknowledgments}

The authors express their gratitude to the staff of the in vitro fertilization laboratory, Vitrogen (Uberaba, MG, Brazil), for their contribution to the present study. Special thanks to Luciano Borges for supporting the study by providing the animals. M.R.S was the recipient of a studentship from Fundação Araucária, PR-Brasil.

\section{References}

Aardema, H., Vos, P. L. A. M., Lolicato, F., Roelen, B. A. J., Knijn, H. M., Vaandrager, A. B.,... Gadella, B. M. (2011). Oleic acid prevents detrimental effects of saturated fatty acids on bovine oocyte developmental competence1. Biology of Reproduction, 85(1), 6269. doi: 10.1095/biolreprod.110.088815

Adamiak, S. J., Powell, K., Rooke, J. A., Webb, R., \& Sinclair, K. D. (2006). Body composition, dietary carbohydrates and fatty acids determine postfertilisation development of bovine oocytes in vitro. Reproduction, 131(2), 247-258. doi: 10.1530/ rep. 1.00871

Association of Official Analytical Chemists (1998). Official methods of analysis (16nd ed.). Gaithersburg, M.P.: AOAC.

Bilby, T. R., Block, J., Amaral, B. C. do, Sa, O., F., Silvestre, F. T., Hansen, P. J.,... Thatcher, W. W. (2006). Effects of dietary unsaturated fatty acids on oocyte quality and follicular development in lactating dairy cows in summer. Journal of Dairy Science, 89(10), 3891-3903. doi: 10.3168/jds.S00220302(06) 72432-8

Bó, G. A., Cedeño,A., \& Mapletoft, R. J. (2019). Strategies to increment in vivo and in vitro embryo production and transfer in cattle. Animal Reproduction, 16(3), 411-422. doi: 10.21451/1984-3143-AR 2019-0042

Cerri, R. L. A., Juchem, S. O., Chebel, R. C., Rutigliano, H. M., Bruno, R. G. S., Galvão, K. N.,... Santos, J. E. P. (2009). Effect of fat source differing in fatty acid profile on metabolic parameters, fertilization, and embryo quality in high-producing dairy cows. Journal of Dairy Science, 92(4), 1520-1531. doi: $10.3168 /$ jds.2008-1614

Cooke, R. F. (2019). Early career achievement award: Supplementing omega- 6 fatty acids to enhance early embryonic development and pregnancy establishment in Bos indicus and B. taurus beef cows. Journal of Animal Science, 97(1), 485-495. doi: 10.1093/jas/sky414

Curran, S., Kastelic, J. P., \& Ginther, O. J. (1989). Determining sex of the bovine fetus by ultrasonic assessment of the relative location of the genital tubercle. Animal Production Science, 19(3), 217227. doi: $10.1016 / 0378-4320(89) 90095-X$ 
Ferguson, J. D., Sklan, D., Chalupa, W. V., \& Kronfeld, D. S. (1990). Effects of hard fats on in vitro and in vivo rumen fermentation, milk production, and reproduction in dairy cows. Journal of Dairy Science, 73(10), 2864-2879. doi: 10.3168/jds.S00220302(90)78974-6

Fouladi-Nashta, A. A., Gutierrez, C. G., Gong, J. G., Garnsworthy, P. C., \& Webb, R. (2007). Impact of dietary fatty acids on oocyte quality and development in lactating dairy cows. Biology of Reproduction, 77(1), 9-17. doi: 10.1095/biolreprod.106.058578

Fouladi-Nashta, A. A., Wonnacott, K. E., Gutierrez, C. G., Gong, J. G., Sinclair, K. D., Garnsworthy, P. C., \& Webb, R. (2009). Oocyte quality in lactating dairy cows fed on high levels of n-3 and n-6 fatty acids. Reproduction, 138(5), 771-781. doi: 10.1530/REP08-0391

Funston, R. N. (2004). Fat supplementation and reproduction in beef females. Journal of Animal Science, 82(E-Suppl.) E154-161. doi: 10.2527/2004.8213_supplE154x

Green, M. P., Spate, L. D., Parks, T. E., Kimura, K., Murphy, C. N., Williams, J. E.,... Roberts, R. M. (2008). Nutritional skewing of conceptus sex in sheep: effects of a maternal diet enriched in rumenprotected polyunsaturated fatty acids (PUFA). Reproductive Biology and Endocrinology : RB\&E, 6(21), 1-11. doi: 10.1186/1477-7827-6-21

Gutiérrez-Adán, A., Behboodi, E., Andersen, G. B., Medrano, J. F., \& Murray, J. D. (1996). Relationship between stage of development and sex of bovine IVM-IVF embryos cultured in vitro versus in the sheep oviduct. Theriogenology, 46(3), 515-528. doi: 10.1016/0093-691X(96)00173-2

Gutiérrez-Adán, A., Lonergan, P., Rizos, D., Ward, F. A., Boland, M. P., Pintado, B., \& de la Fuente, J. (2001). Effect of the in vitro culture system on the kinetics of blastocyst development and sex ratio of bovine embryos. Theriogenology, 55(5), 1117-1126. doi: 10.1016/S0093-691X(01)00471-X

Hiller, B. (2014). Recent developments in lipid metabolism in ruminants - the role of fat in maintaining animal health and performance. Animal Production Science, 54(10), 1549-1560. doi: 10.1071/AN14555

Lonergan, P., \& Fair, T. (2008). In vitro-produced bovine embryos: dealing with the warts. Theriogenology, 69(1), 17-22. doi: 10.1016/j. theriogenology.2007.09.007

Lopes, C. N., Cooke, R. F., Reis, M. M., Peres, R. F., \& Vasconcelos, J. L. (2011). Strategic supplementation of calcium salts of polyunsaturated fatty acids to enhance reproductive performance of Bos indicus beef cows. Journal of Animal Science, 89(10), 31163124. doi: 10.2527/jas.2011-3909

Lopes, C. N., Scarpa, A. B., Cappellozza, B. I., Cooke, R. F., \& Vasconcelos, J. L. M. (2009). Effects of rumenprotected polyunsaturated fatty acid supplementation on reproductive performance of Bos indicus beef cows. Journal of Animal Science, 87(12), 39353943. doi: $10.2527 /$ jas.2009-2201

Mattos, R., Staples, C. R., \& Thatcher, W. W. (2000). Effects of dietary fatty acids on reproduction in ruminants. Reviews of Reproduction, 5(1), 38-45. doi: 10.1530/ror.0.0050038

Meikle, A., Brun, V. de, Carriquiry, M., Soca, P., Sosa, C., Adrien, M. de L.,... Abecia, J. A. (2018). Influences of nutrition and metabolism on reproduction of the female ruminant. Animal Reproduction, 15(1), 899911. doi: 10.21451/1984-3143-AR2018-0017

Mertens, D. R. (2002). Gravimetric determination of amylase-treated neutral detergent fiber in feeds with refluxing in beakers or crucibles: collaborative study. Journal of AOAC International, 85(6), 1217-1240. doi: 10.1093/jaoac/85.6.1217

National Research Council (1996). Nutrients requirements of beef cattle ( $7 \mathrm{nd}$ ed.). Washington, D.C.: The National Academies Press.

Parrish, J. J., Susko-Parrish, J. L., Leibfried-Rutledge, M. L., Critser, E. S., Eyestone, W. H., \& First, N. L. 1986. Bovine in vitro fertilization with frozenthawed semen. Theriogenology 25(4), 591-600. doi: 10. 1016/0093-691x(86)90143-3

Peterson, A. J., \& Lee, R. S. (2003). Improving successful pregnancies after embryo transfer. Theriogenology, 59(2), 687-697. doi: 10.1016/ s0093-691x(02)01248-7

Ponter, A. A., Guyader-Joly, C., Nuttinck, F., Grimard, B., \& Humblot, P. (2012). Oocyte and embryo production and quality after OPU-IVF in dairy heifers given diets varying in their n-6/n-3 fatty acid ratio. Theriogenology, 78(3), 632-645. doi: 10.1016/j.theriogenology.2012.03.009

Pontes, J. H., Nonato, I., Jr., Sanches, B. V., Ereno, J. C., Jr., Uvo, S., Barreiros, T. R.,... Seneda, M. M. (2009). Comparison of embryo yield and pregnancy rate between in vivo and in vitro methods in the same Nelore (Bos indicus) donor cows. Theriogenology, 71(4), 690-697. doi: 10.1016/j.theriogenology.2008. 09.031 
Richards, M. W., Spitzer, J. C., \& Warner, M. B. (1986). Effect of varying levels of postpartum nutrition and body condition at calving on subsequent reproductive performance in beef cattle. Journal of Animal Science, 62(2), 300-306. doi: 10.2527/ jas1986.622300x

Rizos, D., Clemente, M., Bermejo-Alvarez, P., de La Fuente, J., Lonergan, P., \& Gutierrez-Adan, A. (2008). Consequences of in vitro culture conditions on embryo development and quality. Reproduction in Domestic Animals = Zuchthygiene, 43(Suppl. 4), 44-50. doi: 10.1111/j.1439-0531.2008.01230.x

Rizos, D., Ward, F., Duffy, P., Boland, M. P., \& Lonergan, P. (2002). Consequences of bovine oocyte maturation, fertilization or early embryo development in vitro versus in vivo: implications for blastocyst yield and blastocyst quality. Molecular Reproduction and Development, 61(2), 234-248. doi: 10.1002/ $\operatorname{mrd} .1153$

Robertson, I., \& Nelson, R. E. (1998). Certification and identification of the embryo. In D. A. Stringfellow, \& S. M. Seidel (Eds.), Manual of the international embryo transfer society (pp. 103-134). Savoy: IETS

Santos, J. E. P., Bilby, T. R., Thatcher, W. W., Staples, C. R., \& Silvestre, F. T. (2008). Long chain fatty acids of diet as factors influencing reproduction in cattle. Reproduction in Domestic Animals, 43(Suppl. 2), 23-30. doi: 10.1111/j.1439-0531.2008.01139.x

Siqueira, L. G., Torres, C. A., Amorim, L. S., Souza, E. D., Camargo, L. S., Fernandes, C. A., \& Viana, J. H. (2009). Interrelationships among morphology, echotexture, and function of the bovine corpus luteum during the estrous cycle. Animal Production Science, 115(1-4), 18-28. doi: 10.1016/j.anireprosci.2008. 11.009

Souza, M. R. de, Santos, G. T. dos, Lima, L. S. de, Mazucheli, J., Zeoula, L. M., Rigolon, L. P., \& Cavalieri, F. L. B. (2016). Oocyte production in Nellore cows supplemented with long-chain fatty acid soaps. Revista Brasileira de Zootecnia, 45(3), 138-143. doi: 10.1590/S1806-92902016000300008

Swecker, W. S. (2014). Interaction of nutrition and reproduction in the beef cow. In R. M. Hopper, Bovine reproduction (pp. 276-282). Hoboken, NJ: John Wiley \& Sons, Inc.

Thangavelu, G., Colazo, M. G., Ambrose, D. J., Oba, M., Okine, E. K., \& Dyck, M. K. (2007). Diets enriched in unsaturated fatty acids enhance early embryonic development in lactating Holstein cows. Theriogenology, 68(7), 949-957. doi: 10.1016/j. theriogenology.2007.07.002

Van Wagtendonk-de Leeuw, A. M., Mullaart, E., de Roos, A. P., Merton, J. S., den Daas, J. H., Kemp, B., \& de Ruigh, L. (2000). Effects of different reproduction techniques: AI MOET or IVP, on health and welfare of bovine offspring. Theriogenology, 53(2), 575597. Recovered from http://www.ncbi.nlm. nih.gov/ pubmed/10735051

Zeron, Y., Sklan, D., \& Arav, A. (2002). Effect of polyunsaturated fatty acid supplementation on biophysical parameters and chilling sensitivity of ewe oocytes. Molecular Reproduction and Development, 61(2), 271-278. doi: 10.1002/mrd.1156 
